\title{
Studi Empirik \\ Kebutuhan Prestasi, Norma Subjektif, Efikasi Diri Terhadap Intensi Kewirausahaan Mahasiswa Di Tiap Fakultas di Universitas Muhammadiyah Jember
}

\author{
Retno Endah Supeni ${ }^{1}$, Bayu Wijayantini ${ }^{2}$, Gustina Ferdiawati ${ }^{3}$ \\ FEB UM Jember ${ }^{1}$, FEB UM Jember ${ }^{2}$, PT. Tamimi Wisata Tour And Travel Surabaya ${ }^{3}$ \\ Email: : retnoendahsupeni@unmuhjember.ac.id ${ }^{1,}$ bayu@unmuhjember.ac.id \\ , gustinaferdiawati24@gmail.com³
}

\begin{abstract}
Abstrak: Tujuan penelitian adalah menguji dan menganalisis signifikansi secara parsial variabel kebutuhan berprestasi, norma subyektif dan efikasi mempengaruhi intensi kewirausahaan mahasiswa tiap-tiap fakultas di UM Jember. Data diambil dengan wawancara mendalam dan observasi, menggunakan pendekatan kuantitatif diskriptif dengan metode regresi linier berganda, pengujian Uji t dan Uji F (SPSS). Responden sebanyak 385 mahasiswa tersebar di tiap Fakutas di UM Jember. Hasil penelitian melaporkan bahwa secara partial variabel signifikan yang memengaruhi intensi kewirausahaan di UM Jember adalah norma subyektif, sedangkan kebutuhan prestasi dan efikasi diri tidak signifikan memengaruhi intensitas kewirausahaan. Pada tiap-tiap Fakutas variabel kebutuhan prestasi, norma subyektif dan efikasi diri memilik hasil yang berbeda, variabel kebutuhan prestasi yang tidak memengaruhi signifikan terhadap intensi kewirausahaan di FKIP, FSOSPOL, FIKES, AKPAR, dan norma subyektik hanya di F Psikologi dan FKIP saja tidak memengaruhi intensitas kewirausahaan sedang efikasi diri di $F$ Psikologi dan AKPAR yang tidak memengaruhi signifikan terhadap intensitas kewirausahaan. Implikasi penelitian memberikan informasi mengenai strategi pengembangan intensi kewirausahaan pada Perguruan tinggi khusunya kebijakan yang perlu dilakukkan di tiap-tiap Fakultas UM Jember
\end{abstract}

Kata Kunci : Kebutuhan Prestasi, Norma Subjektif, Efikasi Diri Dan Intensi Kewirausahaan

Intensi menunjukkan faktor-faktor motivasional yang mempengaruhi perilaku dan merupakan indikasi-indikasi tentang betapa sulitnya orangorang bersedia untuk berusaha, serta seberapa banyak upaya yang mereka rencanakan untuk digunakan dalam melaksanakan perilaku tersebut (Hisrich dkk, 2017).Tanjungsari (2013) melaporkan masih rendahnya jumlah wirausaha di Indonesia menunjukkan bahwa intensi berwirausaha masih rendah dan intensi berwirausaha merupakan langkah pertama yang perlu dipahami dari sebuah proses pembentukan usaha yang seringkali memerlukan waktu dalam jangka panjang. Menurut Krueger, et al (2000) intensi merupakan prediktor terbaik bagi sebagian besar perilaku terencana, termasuk dalam perilaku berwirausaha sedang Hisrich dkk., (2017), intensi berwirausaha menunjukkan komitmen seseorang untuk memulai berwirausaha dan mempelajari hal mengenai kewirausahaan. Indarti dan Rostiani (2008) menunjukkan bahwa beberapa faktor yang mempengaruhi intensi berwirausaha yaitu faktor pribadi (kebutuhan akan prestasi, efikasi diri, internal locus of control, dan pengambilan risiko), faktor lingkungan (akses kepada modal informasi dan jaringan sosial), dan faktor demografi (gender, umur latar belakang pendidikan, pekerjaan orang tua, dan pengalaman kerja). 
McClelland $(1961,1971)$ telah memperkenalkan konsep kebutuhan akan prestasi sebagai salah satu motif psikologis. Kebutuhan akan prestasi dapat diartikan sebagai suatu kesatuan watak yang memotivasi seseorang untuk menghadapi tantangan untuk mencapai kesuksesan dan keunggulan (Lee, 1997: 103). Lebih lanjut, McClelland (1971) menegaskan bahwa kebutuhan akan prestasi sebagai salah satu karakteristik kepribadian seseorang yang akan mendorong seseorang untuk memiliki intensi kewirausahaan. Hasil penelitian dari Scapinello (1989) menunjukkan bahwa seseorang dengan tingkat kebutuhan akan prestasi yang tinggi kurang dapat menerima kegagalan daripada mereka dengan kebutuhan akan prestasi rendah. Dengan kata lain, kebutuhan akan prestasi berpengaruh pada atribut kesuksesan dan kegagalan. Sejalan dengan hal tersebut, Sengupta dan Debnath (1994) dalam penelitiannya di India menemukan bahwa kebutuhan akan prestasi berpengaruh besar dalam tingkat kesuksesan seorang wirausaha. Namun Indarti dan Rostianti (2008) melaporkan bahwa kebutuhan akan prestasi, umur, dan gender tidak terbukti secara signifikan sebagai prediktor intensi kewirausahaan.

Faktor lain yang dapat berpengaruh terhadap intensi adalah norma subjektif dimana berdasarkan theory of planned behavior oleh Ajzen (2005). Seorang wirausaha harus mempunyai norma subjektif agar lebih yakin dan semangat untuk memulai membuka usaha. Norma subjektif yaitu keyakinan individu untuk mematuhi arahan atau anjuran orang di sekitarnya untuk turut dalam melakukan aktivitas berwirausaha (Andika dan Madjid, 2012). Norma subjektif memiliki peran penting dalam meningkatkan intensi berwirausaha karena norma subjektif merupakan bentuk dukungan dari orang lain (significant others) seperti orang tua, pasangan, teman dekat, rekan kerja atau lainnya dimana dalam konteks ini dukungan untuk berwirausaha. Beberapa penelitian yang dilakukan oleh Costa dan Mares (2016), Prabandari dan Sholihah (2014), Jaya dan Seminari (2016) serta Mardliyah dkk. (2016) menyatakan bahwa norma subjektif berpengaruh terhadap intensi berwirausaha pada mahasiswa. Hasil berbeda ditunjukkan oleh penelitian yang dilakukan oleh Andika dan Madjid (2012), Dinc dan Budic (2016). Bandura (1977) mendefinisikan efikasi diri sebagai kepercayaan seseorang atas kemampuan dirinya untuk menyelesaikan suatu pekerjaan. Atau dengan kata lain kondisi motivasi seseorang yang lebih didasarkan pada apa yang mereka percaya daripada apa yang secara objektif benar. Persepsi pribadi seperti ini memegang peranan penting dalam pengembangan intensi seseorang. Senada dengan hal tersebut, Cromie (2000) menjelaskan bahwa efikasi diri mempengaruhi kepercayaan seseorang pada tercapai atau tidaknya tujuan yang sudah ditetapkan. Luthans (2008) menunjukkan bahwa efikasi diri dianggap penting karena dapat mendorong kinerja seseorang dalam berbagai bidang termasuk intensi berwirausaha. Dalam berwirausaha sangatlah penting seseorang yakin akan kemampuannya, termasuk keyakinan dalam memulai usaha dan menghadapi berbagai 
risiko. Jika intensi berwirausaha tanpa disertai efikasi diri yang tinggi maka bisa dipastikan bahwa niatnya hanya akan menjadi cita-cita yang tak berwujud (Wulan Oktabriyantina, dkk., 2014). Farida dan Mahmud (2015), Wiyanto (2014) menunjukkan bahwa efikasi diri berpengaruh signifikan terhadap intensi mata kuliah entrepreneurship yang berdampak pada intensi mahasiswa berwirausaha. Selanjutnya, Wijaya dalam Wiyanto (2014) serta Defriana (2011) menyatakan bahwa efikasi diri terbukti tidak mempengaruhi intensi berwirausaha.

Tingkat Pengangguran Terbuka (TPT) berdasarkan data resmi Badan Pusat Statistik (BPS) mencapai 7,05 juta orang per Agustus 2019, dimana mengalami peningkatan dari tahun lalu sebelumnya . Akan tetapi secara persentase, TPT turun menjadi 5,28\% dibandingkan tahun lalu yang sebesar 5,34\%. (Sindo New , Selasa, 5 November 2019 - 14:38 WIB). Persentase jumlah pengangguran terhadap jumlah angkatan kerja mengindikasikan besarnya persentase angkatan kerja yang termasuk dalam pengangguran. Data Tingkat Pengangguran Terbuka (TPT) Kabupaten Jember tahun 2014 sebesar 4,64\% ; tahun 2015 sebesar 4,77 \% ; tahun 2017 sebesar 5,16 \% dan pada tahun 2019 justru menurun $3,80 \%$. Penurunan ini akibat kebijakan pemerintah daerah yang mengharuskan investor merekrut tenaga kerja ber-KTP Jember. Penurunan ini dipaparkan oleh Badan Pusat Stastistik (BPS) Kabupaten Jember di ruang Tamyaloka Pendapa Wahyawibawagraha, Jum"at 1 Februari 2019. Tingkat persaingan tenaga kerja di Indonesia yang masih ketat dan selektif membawa dampak pada kesadaran untuk tidak terlalu berharap pada lapangan pekerjaan yang ada di masyarakat. Fenomena pengangguran juga menimpa Jember merupakan salah satu kota pendidikan, setiap tahun menghasilkan lulusan sarjana yang cukup besar bahkan ribuan lulusan sarjana, namun penyerapan tenaga kerja perusahaan sangat terbatas. Oleh sebab itu perguruan tinggi negeri maupun swasta diharapkan mampu menyiapkan lulusan untuk menjadi wirausaha yang unggul agar tidak menggantungkan kerja pada orang lain, tetapi diperlukan keberanian untuk membuka usaha sendiri atau berwirausaha.

Zimmerer (2002) dalam HIPMI PT Unand (2015) menyatakan salah satu faktor pendorong pertumbuhan kewirausahaan disuatu negara terletak pada peranan universitas melalui penyelenggaraan pendidikan kewirausahaan. Pihak universitas bertanggung jawab dalam mendidik dan memberikan kemampuan wirausaha kepada para lulusannya dan memberikan motivasi untuk berani memilih berwirausaha sebagai karir mereka. Pihak perguruan tinggi perlu menerapkan pola pembelajaran kewirausahaan yang konkrit berdasar masukan empiris untuk membekali mahasiswa dengan pengetahuan yang bermakna agar dapat mendorong semangat mahasiswa untuk berwirausaha (Suherti dan Sirine, 2011).

Penggunaan teori perilaku tidak dapat dipisahkan dari aspek motivasi berwirausaha atau entrepreneurial intention, artinya kewirausahaan dapat dipelajari dan dikuasai, dan kewirausahaan dapat 
menjadi pilihan kerja dan pilihan karir bagi lulusan perguruan tinggi, apabila memang dalam diri mahasiswa ada niat dan motivasi untuk menjadi seorang entrepreneur, Surya (2017) dan Sarwoko (2011) mengatakan, seberapa besar entrepreneurial intention atau motivasi mahasiswa menjadi wirausaha tentunya akan dipengaruhi atau ditentukan oleh beberapa faktor. Oleh karena itu perlu diketahui faktor-faktor yang mempengaruhi motivasi mahasiswa untuk menjadi entrepreneur atau intensi menjadi entrepreneur.

Kenyataan menunjukkan bahwa sebagian besar lulusan perguruan tinggi adalah lebih sebagai pencari kerja (job seeker) dari pada pencipta lapangan pekerjaan (job creator).Survei peneliti (Des 2020) terhadap mahasiswa seluruh Fakultas di lingkungan UM Jember terdapat sebanyak sekitar $41 \%$ mahasiswa sebagai job creator dengan minat berwirausaha sedangkan $59 \%$ sebagai Job seekers. Masih banyaknya faktor-faktor yang dipertimbangkan mahasiswa sehingga menyebabkan mahasiswa kurang menyukai berwirausaha, sebagian besar mahasiswa lebih menyukai jalan aman daripada berwirausaha. Meskipun banyak mahasiswa UM Jember ebagai job seekers namun mahasiswa hampir mendekati separuh mahasiswa di tiap Fakultas di lingkungan UM Jember yang berminat berwirausaha, hal ini menarik untuk dikaji penyebab mahasiswa memiliki ketertarikan berwirausaha (entrepreneurial intention). Beberapa teorik dan temun empirik tentang intensi kewirausahaan dan variabel kebutuhan prestasi, norma subjektif, efikasi diri yang mempengaruhinya telah disampaikan dan diteliti oleh Scapinello (1989), Theory of planned behavior oleh Ajzen (2005). McClelland (1961, 1971) : Bandura (1977: 2); Sengupta dan Debnath (1994); Lee, (1997): Krueger, et al (2000); Cromie (2000); Luthans (2008); Indarti dan Rostiani (2008); Sri Defriana (2011) Sarwoko (2011) (Andika dan Madjid, 2012); (Andika dan Madjid, 2012). Wiyanto (2014) Costa dan Mares (2016), Prabandari dan Sholihah (2014), (Wulan Oktabriyantina, dkk., 2014). Farida dan Mahmud (2015), Islami (2015), Jaya dan Seminari (2016) serta Mardliyah dkk. (2016); Adi Jaya Dan Seminari (2016), Dinc dan Budic (2016) Surya (2017) Bryan (2018) Siswati (2019) . Beberapa temuan tersebut masih memiliki perbedaan hasil penelitian ada yang melaporkan bahwa kebutuhan berprestasi, norma subyektif dan efikasi mempengaruhi terhadap intensi kewirausahaan namun ada juga yang menunjukkan sebaliknya. Penelitian ini menduga bahwa variabel yang mempengaruhi secara signfikan intensi kewirausahaan mahasiswa yang berada pada tiap-tiap Fakultas di UM Jember adalah kebutuhan berprestasi, norma subyektif dan efikasi. Tujuan penelitian adalah menguji dan menganalisis signifikansi secara parsial variabel kebutuhan berprestasi, norma subyektif dan efikasi mempengaruhi intensi kewirausahaan mahasiswa tiap-tiap fakultas di UM Jember. 


\section{METODE}

Populasi penelitian adalah seluruh mahasiswa di tiap Fakultas di UM Jember sebanyak 10.421 Orang. Sampel penelitian menggunakan rumus Slovin sebanyak 385 mahasiswa yang tersebardi Fakultas Hukum, Fakultas KIP, Fakultas Psikologi, Fakultas Ekonomi, Fakultas Pertanian, Fakultas Teknik, Fakultas IImu Kesehatan, Fakultas IImu Sosial dan Politik dan Akademi Pariwisata di lingkungan Universitas Muhammadiyah dengan proporsional sampling . Identifikasi variabel penelitian $X_{1=}$ Kebutuhan Berprestasi; $X_{2}=$ Norma Subyektif; $X_{3}=$ Efikasi Diri dan $Y=$ Intensi Kewirausahaan .

Penggalian data dilakukan melalui proses wawancara mendalam dan observasi. Wawancara dilakukan dengan menggunakan pertanyaan terbuka dan tertutup. Data yang digali adalah data primer dan diinterpretasikan dengan melakukan review terhadap jurnal, buku dan artikel yang relevan. Pengujian instrument penelitian Uji Validitas dan uji Realiabilitas, Uji validitas dalam penelitian ini dilakukan dengan metode Pearson Product Moment. Suliyanto (2005) mengemukakan bahwa keputusan pada sebuah butir pertanyaan dapat dianggap valid jika koefisien korelasi Product Moment melebihi 0,30. Sedangkan Uji Reliabilitas, menunjukkan sejauh mana suatu alat ukur konsisten atau memiliki kemantapan dalam penggunaanya, ( Nugroho, 2005) yang menyatakan bahwa sebuah data dikatakan reliabel apabila nilai a lebih besar dari 0,60. Analisis Regresi Linier Berganda, digunakan untuk mengetahui pengaruh signifikan variabel kebutuhan prestasi, norma subyektif, efikasi diri terhadap intensi kewirausahaan (Prayitno, 2010:61). Uji Asumsi Klasik, Uji Normalitas untuk menguji apakah variabel dependen, indenpenden atau keduanya berdistribusi normal, mendekati normal atau tidak (Herryanto \& Gantini, 2015) . Uji Multikolinearitas untuk menguji hubungan linear yang "sempurna" atau pasti, diantara beberapa atau semua variable yang menjelaskan dari model regresi. Uji Heteroskedastisitas untuk menguji apakah dalam model regresi terjadi ketidaksamaan varian dari residual satu observasi ke observasi yang lain. Uji Hipotesis, Uji t (uji parsial), yaitu uji untuk mengetahui pengaruh variabel-variabel independen secara parsial terhadap variabel dependen (Herryanto \& Gantini, 2015) Dan Uji F (Uji Simultan) untuk mengetahui apakah secara simultan koefisien variabel independen mempunyai pengaruh nyata atau tidak terhadap variabel dependen (Sugiyono, 2012), Koefisien Determinasi Berganda $\left(R^{2}\right)$, digunakan untuk mengetahui besarnya pengaruh variabel-variabel independen terhadap variabel dependen secara bersama-sama (Sugiyono, 2012),

\section{HASIL}

Diskripsi statistik responden sebanyak 385 mahasiswa yaitu mahasiswa yang tersebar di Fakultas Fakultas Hukum $(10,4 \%)$ KIP $(11,4 \%)$, Psikologi $(10,4 \%)$ Ekonomi (12,8\%), Pertanian (10,4\%), Tehnik $(10,4 \%)$, IImu kesehatan $(11,4 \%)$, IImu Sosial Politik $(11,4 \%)$ dan 
Pariwisata $(11,4 \%)$ di lingkungan UM Jember. Statistik responden menurut usia yaiutu $46,7 \%$ berusia di bawah 20 tahun dan sisanya 54,3\% berusia diatas 20 tahun dan menurut jenis kelamin perempuan sebanyak $56 \%$, laki-laki 43,9\%. Karakteristik usia dan jenis kelamin menjadi faktor-faktor yang mempengaruhi intensi wirausaha dan juga lingkungan (lingkungan keluarga, lingkungan pendidikan, lingkungan masyarakat), kepribadian (ektraversi, kesepahaman / agreebleeness, berani mengambil resiko, kebutuhan berprestasi, independen, evaluasi diri dll. Penelitian yang dilakukan oleh Sinha (1996) di India, menunjukkan bahwa hampir sebagian besar wirausaha yang sukses adalah mereka yang berusia relatif muda. Hal ini senada dengan Reynolds et al., (2000) yang menyatakan bahwa seseorang berusia 25-44 tahun adalah usia-usia paling aktif untuk berwirausaha di negara-negara barat. namun penelitian ini tidak menganalisis beberapa variabel usia dan jenis kelamin .

Hasil Pengujian instrument penelitian menunjukkan Uji Validitas korelasi antara masing-masing indikator terhadap total skor kontruk dari setiap variabel menunjukkan hasil yang valid, karena $r$ hitung $>r$ tabel dan nilai signifikansi $<0,05$. Sehingga dapat disimpulkan bahwa semua item pernyataan dinyatakan valid. Dan hasil uji reliabilitas tersebut menunjukkan bahwa semua variabel mempunyai koefisien alpha yang cukup atau memenuhi kriteria untuk dikatakan reliabel yaitu diatas 0,600, sehingga untuk selanjutnya item-item pada masing-masing konsep variabel tersebut layak digunakan sebagai alat ukur.

Persamaan regresi berganda yang terbentuk adalah:

$Y=3,044+0,022 X_{1}+0,248 X_{2}-0,013 X_{3}+e_{i} ;$ dimana :

$\mathrm{Y}=$ Intensi Kewirausahaan; $\mathrm{X}_{1}=$ Kebutuhan Berprestasi $; \mathrm{X}_{2}=$ Norma Subjektif ; $X_{3}=$ Efikasi Diri.

Tabel 1 Hasil Analisis Regresi Linier Berganda Mahasiswa UM Jember

\begin{tabular}{|c|c|c|c|c|c|c|}
\hline \multicolumn{7}{|c|}{ Coefficients" } \\
\hline \multirow{2}{*}{\multicolumn{2}{|c|}{ Mode1 }} & \multicolumn{2}{|c|}{$\begin{array}{l}\text { Unstandardized } \\
\text { Coefficients }\end{array}$} & \multirow{2}{*}{$\begin{array}{l}\text { Standardized } \\
\text { Coefficients } \\
\text { Beta }\end{array}$} & \multirow[b]{2}{*}{$t$} & \multirow[b]{2}{*}{ Sig. } \\
\hline & & B & Std. Error & & & \\
\hline \multirow[t]{5}{*}{$\overline{1}$} & (Constant) & 3,044 & .364 & & 8,371 & .000 \\
\hline & Kebutuhan & .022 & .050 & .022 & $=448$ & .655 \\
\hline & Berprestasi & & & & & \\
\hline & Norma Subjektif & .284 & .049 & .290 & 5,856 &, 000 \\
\hline & Efikasi Diri & -.013 & .049 &,- 013 & -.272 & .786 \\
\hline
\end{tabular}

Sumber: Data Primer diolah , Des 2020 (SPSS)

Selanjutnya dilakukan analisis regresi berganda pada tiap-tiap Fakultas di lingkungan UM Jember pada tabel 2 :

Tabel 2 Hasil Analisis Regresi Berganda Tiap Fakultas

\begin{tabular}{clccccccccc}
\hline & & \multicolumn{10}{c}{ B/sig. } \\
\cline { 3 - 11 } No. & Variabel & $\begin{array}{c}\text { F.Hukum } \\
(n=40)\end{array}$ & $\begin{array}{c}\text { FKIP } \\
(n=44)\end{array}$ & $\begin{array}{c}\text { F. Psik } \\
(n=40)\end{array}$ & $\begin{array}{c}\text { Fk. Eko } \\
(n=49)\end{array}$ & $\begin{array}{c}\text { Pertani } \\
(n=40)\end{array}$ & $\begin{array}{c}\text { Teknik } \\
(n=40)\end{array}$ & $\begin{array}{c}\text { FIKES } \\
(n=44)\end{array}$ & $\begin{array}{c}\text { FISIP } \\
(n=44)\end{array}$ & $\begin{array}{c}\text { AKPAR } \\
(n=44)\end{array}$ \\
1. & Kebutuhan & $-0,167 /$ & $-0,086 /$ & $-0,169 /$ & $0,089 /$ &,$- 0196 /$ & $-0,042 /$ & $0,080 /$ & $-0,043 /$ & $0,065 /$ \\
& Prestasi & 0,323 & 0,558 & 0,419 & 0,490 & 0,255 & 0,803 & 0,577 & 0,790 & 0,711 \\
2. & Norma & $0,168 /$ & $0,089 /$ & $-0,080 /$ & $-0,126 /$ & $0,533 /$ & $0,167 /$ & $0,422 /$ & $0,022 /$ & $0,244 /$ \\
& Subyektif & 0,249 & 0,586 & 0,676 & 0,377 & 0,006 & 0,227 & 0,003 & 0,147 & 0,132 \\
3. & Efikasi Diri & $-0,118$ & $0,247 /$ & $0,029 /$ & $-0,132 /$ & $-0,133 /$ & $-0,147 /$ & $-0,025 /$ & $0,052 /$ & $-0,079$ \\
\hline
\end{tabular}


Sumber: Data Primer diolah, Des 2020 (SPSS)

Pengujian data terdistribusi secara normal, sebaran data berada disekitar garis diagonal. Hal ini menunjukkan bahwa model regresi dalam penelitian ini memenuhi asumsi normalitas.

Niilai VIF semua variabel bebas dalam penelitian ini lebih kecil dari 10 sedangkan nilai tolerance semua variabel bebas lebih dari $10 \%$ yang berarti tidak terjadi kolerasi antar variabel bebas yang nialinya lebih dari $90 \%$, dengan demikian dapat disimpulkan bahwa tidak terdapat gejala multikolinearitas antar variabel bebas dalam model regresi. Hasil uji heteroskedastisitas yang telah dilakukan ternyata titik-titik menyebar secara acak, membentuk suatu pola tertentu yang jelas, serta tersebar secara baik diatas maupun dibawah angka 0 (nol) pada sumbu $Y$, hal ini berarti tidak terjadi penyimpangan asumsi klasik heteroskedatisitas pada model regresi yang dibuat

.Hasil Uji F menunjukkan bahwa Fhitu $n g>$ Ftabel $(11,548>2,6284)$ maka kebutuhan berprestasi, norma subjektif dan efikasi diri mempunyai pengaruh simultan signifikan terhadap intensi kewirausahaan mahasiswa

Hasil Uji t (tabel 1) menunjukkan kebutuhan berprestasi mempunyai signifikansi hitung sebesar 0,655 dan lebih besar dari 0,05 dan thitung $(0,448)<$ ttabel $(1,966)$ yang berarti bahwa hipotesis kebutuhan berprestasi tidak mempunyai pengaruh signifikan secara partial terhadap intensi kewirausahaan mahasiswa UM Jember. Hal ini menunjukkan bahwa kebutuhan berprestasi tidak mempengaruhi intensi kewirausahaan mahasiswa. Norma subjektif mempunyai nilai signifikansi sbesar 0,000 dan lebih kecil dari 0,05 dan thitung $(5,856)>$ ttabel $(1,966)$ yang berarti bahwa hipotesis norma subjektif mempunyai pengaruh secara partial terhadap intensi kewirausahaan mahasiswa .. Hal ini menunjukkan bahwa norma subjektif mempengaruhi intensi kewirausahaan mahasiswa yang berarti semakin baik norma subjektif akan berdampak pada semakin tingginya intensi kewirausahaan. Efikasi diri mempunyai signifikansi hitung sebesar 0,786 dan lebih besar dari 0,05 dan thitung $(-0,272)<$ ttabel $(1,966)$ yang berarti bahwa hipotesis efikasi diri tidak mempunyai pengaruh partia signifikan terhadap intensi kewirausahaan mahasiswa. Hal ini menunjukkan bahwa efikasi diri tidak mempengaruhi intensi kewirausahaan mahasiswa UM Jember .

Koefisien determinasi yang diperoleh sebesar, 077 . Hal ini berarti $77 \%$ variasi variabel intensi kewirausahaan dapat dijelaskan oleh kebutuhan berprestasi, norma subjektif dan efikasi diri, sedangkan sisanya ,033 atau 33\% diterangkan oleh variabel lain yang tidak diajukan dalam penelitian ini .

Studi empirik ini , menunjukkan bahwa kebutuhan berprestasi, norma subjektif dan efikasi diri mempunyai pengaruh signifikan secara simultan terhadap intensi kewirausahaan mahasiswa UM Jember. Aspek intensi kewirausahaan seseorang telah mendapat perhatian cukup besar dari para peneliti. Intensi kewirausahaan dapat diartikan sebagai proses 
pencarian informasi yang dapat digunakan untuk mencapai tujuan pembentukan suatu usaha (Katz dan Gartner, 1988). Seperti yang dinyatakan oleh Krueger dan Carsrud (1993), intensi telah terbukti menjadi prediktor yang terbaik bagi perilaku kewirausahaan. Oleh karena itu, intensi dapat dijadikan sebagai pendekatan dasar yang masuk akal untuk memahami siapa-siapa yang akan menjadi wirausaha (Choo dan Wong, 2006). Keinginan untuk menyelesaikan suatu tugas dengan sasaran secara lebih efektif. , memiliki kebutuhan berprestasi yang tinggi cenderung menetapkan sasaran yang cukup sulit dan mengambil keputusan yang lebih beresiko mahasiswa UM Jember selaras dengan teori Griffin dan Mourhead (2013) norma obyektif mahasiswa UM Jember ditunjukkan keyakinan individu untuk mematuhi arahan atau anjuran orang sekitarnya, turut dalam aktivitas berwirausaha mendukung temuan Ramayah \& Harun (2005) dan Efikasi diri mengacu pada keyakinan mahasiswa UM Jember bahwa dirinya mampu untuk melaksanakan tugas seperti teori Bandura (1977) bahwa efikasi diri dapat menciptakan spiral yang positif, artinya individu yang memiliki efikasi diri yang tinggi akan lebih terlibat dalam pelaksanaan tugas dan semakin lama hasil yang didapatkan semakin baik . Menurut Krueger, et al (2000) intensi merupakan prediktor terbaik bagi sebagian besar perilaku terencana, termasuk dalam perilaku berwirausaha .

Temuan menunjukkan bahwa kebutuhan berprestasi, norma subyektif, efikasi diri mahasiswa UM Jember secara simutan menjadi prediktor intensi kewirausahaan mahasiswa yaitu perilaku terencana memilih berwirausaha daripada bekerja pada orang lain, memilih berkarir sebagai wirausahawan, melakukan perencanaan untuk memulai usaha, mendapatkan pendapatan yang lebih baik seperti temuan Mutohar (2017):

Study empirik juga menunjukkan temuan (tabel 1 ) bahwa secara partial kebutuhan berprestasi dan efikasi diri tidak mempunyai pengaruh signifikan terhadap intensi kewirausahaan mahasiswa UM Jember namun norma subyektif mahasiswa UM Jember mempunyai pengaruh signifikan terhadap intensi kewirausahaan mahasiswa UM Jember. Kebutuhan prestasi ditunjukkan dengan fenomena tentang tantangan pekerjaan, mencapai hasil yang lebih baik dari sebelumnya., mampu menentukan keputusan. ingin lebih baik dari orang lain tidak mempengaruhi terhadap intensi kewirausahaan mahasiswa UM Jember. Hal ini selaras dengan temuan Indarti \& Rostian (2008).kebutuhan akan prestasi, umur, dan gender tidak terbukti secara signifikan sebagai prediktor intensi kewirausahaan. Namun berbanding terbalik dengan teori McClelland (1971) menegaskan bahwa kebutuhan akan prestasi sebagai salah satu karakteristik kepribadian seseorang yang akan mendorong seseorang untuk memiliki intensi kewirausahaan, Sengupta dan Debnath (1994) dalam penelitiannya di India menemukan bahwa kebutuhan akan prestasi berpengaruh besar dalam tingkat kesuksesan seorang wirausaha demikian pula dengan Yuliandri (2013) melaporkan tingkat kebutuhan akan prestasi, dan tingkat efikasi diri positif sebagai prediktor tingkat minat 
berwirausaha mahasiswa FE Universitas Negeri Padang dan Sarwoko (2011) menunjukkan bahwa kebutuhan berprestasi ternyata tidak berpengaruh signifikan terhadap niat berwirausaha mahasiswa Universitas Kanjuruhan Malang.

Norma subjektif memiliki peran penting dalam meningkatkan intensi berwirausaha karena norma subjektif merupakan bentuk dukungan dari orang lain (significant others) seperti orang tua, pasangan, teman dekat, rekan kerja atau lainnya dimana dalam konteks ini dukungan untuk berwirausaha. Dan fenomena norma subyektif mahasiswa UM Jember tentang keyakinan dan dukungan dari peran keluarga, keyakinan dukungan teman, keyakinan dukungan dari dosen, keyakinan dukungan dari orang yang dianggap penting secara partial signifikan mempengaruhi terhadap intensi kewirausahaan mahasiswa UM Jember. Hasil ini menolak penelitian yang dilakukan oleh Andika dan Madjid (2012), menghasilkan variabel norma subjektif tidak berpengaruh signifikan terhadap intensi berwirausaha, temuain Dinc dan Budic (2016) juga menunjukkan bahwa norma subjektif tidak berpengaruh signifikan terhadap intensi berwirausaha, selanjutnya penelitian yang telah dilakukan oleh Islami (2015) dalam penelitiannya menghasilkan norma subjektif tidak berpengaruh langsung terhadap intensi berwirausaha meskipun berdasarkan theory of planned behavior oleh Ajzen (2005) seorang wirausaha harus mempunyai norma subjektif agar lebih yakin dan semangat untuk memulai membuka usaha, dikatakan bahwa faktor lain yang dapat berpengaruh terhadap intensi adalah norma subjektif . Penelitian ini mendukung beberapa peneliti lain juga melaporkan bahwa norma subjektif berpengaruh terhadap intensi berwirausaha pada mahasiswa oleh Costa dan Mares (2016), peneitian Prabandari dan Sholihah (2014) menunjukkan bahwa norma subjektif berpengaruh signifikan terhadap intensi berwirausaha pada mahasiswa. Selanjutnya Jaya dan Seminari (2016) serta Mardliyah dkk. (2016) juga membuktikan bahwa norma subjektif berpengaruh signifikan terhadap intensi berwirausaha. . Hasil model regresi linier berganda menjawab norma subjektif berpengaruh signifikan positif terhadap intensi berwirausaha siswa SMKN di Denpasar. dilaporkan Adi Jaya Dan Seminari (2016).

Efikasi diri mahasiswa UM Jember yang diukur dari kepercayaan diri, memiliki jiwa kepemimpinan, kematangan mental., penilaian terhadap status psikologis yang dimiliki secara partial tidak signifikan mempengaruhi intensi kewirausahaan mahasiswa UM Jember. Temuan ini mendukung hasil penelitian Wijaya dalam Wiyanto (2014) serta Defriana (2011) menyatakan bahwa efikasi diri terbukti tidak mempengaruhi intensi berwirausaha. Dan sebaiknya menolak teori Bandura (1977) bahwa efikasi diri sebagai kepercayaan seseorang atas kemampuan dirinya untuk menyelesaikan suatu pekerjaan. Atau dengan kata lain kondisi motivasi seseorang yang lebih didasarkan pada apa yang mereka percaya daripada apa yang secara objektif benar dan temuan Luthans (2008), efikasi diri dianggap penting karena dapat 
mendorong kinerja seseorang dalam berbagai bidang termasuk intensi berwirausaha. Dalam berwirausaha sangatlah penting seseorang yakin akan kemampuannya, termasuk keyakinan dalam memulai usaha dan menghadapi berbagai risiko. Jika intensi berwirausaha tanpa disertai efikasi diri yang tinggi maka bisa dipastikan bahwa niatnya hanya akan menjadi cita-cita yang tak berwujud (Wulan Oktabriyantina, dkk., 2014). Beberapa penelitian telah dilakukan mengenai pengaruh efikasi diri signifikan terhadap intensi berwirausaha dilakukan oleh Farida dan Mahmud (2015). , Wiyanto (2014) menyatakan bahwa efikasi diri terbukti mempengaruhi intensi mahasiswa program studi Manajemen FE Universitas Tarumanegara.

Temuan empiri yang terjadi di tiap-tiap fakultas di UM Jember (tabel 2) menunjukkan pengaruh signifikan secara partial kebutuhan prestasi terhadap intensi kewirausahaan mahasiswa terjadi di Fakultas Hukum, Fakultas Psikologi, Fakultas Ekonomi , Fakultas Tehnik , Fakultas Pertanian sedangkan pada Fakultas KIP , Fakultas Sospol, Akademi Pariwisata, Fakultas Kesehatan kebutuhan prestasi secara partial tidak signifikan mempengaruhi intensitas kewirausahaan. Justifikasi bahwa mahasiawa UM Jember di Fakultas KIP, Fakultas Sospol, Akademi Pariwisata , Fakultas Kesehatan bahwa kebutuhan prestasi meliputi tantangan pekerjaan, mencapai hasil yang lebih baik dari sebelumnya., mampu menentukan keputusan. ingin lebih baik dari orang lain , tidak berpengaruh terhadap intensi kewirausahaan lebih karena mayoritas mahasiawa di fakutas tersebut memilih sebagai job seekers dan bukan job creators

Pengaruh signifikan secara partial norma subyektif terhadap intensi kewirausahaan mahasiswa UM Jember terjadi di Fakultas Hukum , Fakultas Ekonomi , Fakultas Tehnik, Fakultas Pertanian, Fakultas Kesehatan, Fakultas Sospol , Akademi Pariwisata sedangkan pada Fakultas KIP, Fakultas Psikologi, kebutuhan prestasi secara partial tidak signifikan mempengaruhi intensitas kewirausahaan. Justifkasi bahwa fakultas FKIP dan Fakultas Psikologi tentang norma subyektif keyakinan dan dukungan dari peran keluarga, keyakinan dukungan teman, keyakinan dukungan dari dosen, keyakinan dukungan dari orang yang dianggap penting tidak mempengaruhi terhadap intensi kewirausahaan disebabkan latar belakang disiplin ilmu di FKIP maupun Fakultas Psikologi , secara psikis tercetak memiliki mental yang kuat mempertahankan keyakinan diri sendiri dan lebih banyak berkeinginan bekerja sesuai bidang ilmunya .

Pengaruh signifikan secara partial efikasi diri terhadap intensi kewirausahaan mahasiswa UM Jember terjadi di Fakultas Hukum , Fakultas Ekonomi, Fakultas Tehnik, Fakultas Pertanian, Fakultas Kesehatan, Fakultas Sospol , Akademi Pariwisata sedangkan pada Fakultas Pariwisata dan Fakultas Psikologi, kebutuhan prestasi secara partial tidak signifikan mempengaruhi intensitas kewirausahaan. 
Jastifikasinya dikarenakan kepercayaan diri, memiliki jiwa kepemimpinan, kematangan mental., penilaian terhadap status psikologis yang dimiliki yang dimiliki Fakultas Psikologi dan Akademi Pariwisata motivasinya lebih kepada sebagai job seekers.

Keterbatasan penelitian ini masih ada kontribusi $33 \%$ variabel diterangkan oleh variabel lain yang tidak diajukan dalam penelitian ini sehingga perlu pengembangan variabel yang di duga mempengaruhi intensi kewirausahaan misal tga faktor lingkungan yang dipercaya mempengaruhi wirausaha yaitu akses mereka kepada modal, informasi, dan kualitas jaringan sosial yang dimiliki, yang kemudian disebut kesiapan instrumen (Indarti, 2004). Intensi kewirausahaan berhubungan juga dengan gender; laki-laki mempunyai intensi kewirausahaan lebih tinggi. Mahasiswa yang berusia muda memiliki intensi kewirausahaan yang lebih tinggi dibandingkan mereka yang berusia tua. Mahasiswa yang berlatar belakang pendidikan ekonomi dan bisnis memiliki intensi kewirausahaan yang lebih tinggi dibandingkan mereka yang berlatar belakang pendidikan non ekonomi dan bisnis. Mahasiswa yang memiliki pengalaman kerja memiliki intensikewirausahaan yang lebih tinggidibandingkan dengan merekayang belum pernah bekerja sebelumnya. Implikasi peneltian ini diharapkan sebagai pertimbangan merencanakan startegi dan kebijakan bagi institusi terkait yaitu Universitas Muhammadiyah Jember khususnya menciptakan kemandirian mahasiswa sebagai job creator dengan meningkatkan intensi kewirausahaan mahasiswa serta prediktornya.

\section{Kesimpulan}

1. Secara partial, penelitian menemukan bahwa variabel signifikan yang mempengaruhi intensi kewirausahaan di UM Jember adalah norma subyektif, sedangkan kebutuhan prestasi dan efikasi diri tidak signifikan memengaruhi intensitas kewirausahaan .

2. Secara partial, penelitian menemukan bahwa variabel signifikan yang mempengaruhi intensi kewirausahaan berbeda antar fakultas seperti temuan variabel kebutuhan prestasi terhadap intensi kewirausahaan mahasiswa terbukti mempunyai pengaruh signifikan di Fakultas Hukum , Fakultas Psikologi, Fakultas Ekonomi, Fakultas Tehnik, Fakultas Pertanian sedangkan pada Fakultas KIP, Fakultas Sospol, Akademi Pariwisata, Fakultas Kesehatan kebutuhan prestasi secara partial tidak signifikan mempengaruhi intensitas kewirausahaan. Variabel norma subyektif mempunyai pengaruh signifikan terhadap intensi kewirausahaan di Fakultas Hukum, Fakultas Ekonomi , Fakultas Tehnik, Fakultas Pertanian, Fakultas Kesehatan, Fakultas Sospol, Akademi Pariwisata sedangkan pada Fakultas KIP dan Fakultas Psikologi, kebutuhan prestasi secara partial tidak signifikan mempengaruhi intensitas kewirausahaan. Variabel efikasi diri terhadap intensi kewirausahaan terbukti mempunyai pengaruh signifikan di Fakultas Hukum, Fakultas Ekonomi, Fakultas Tehnik, Fakultas Pertanian, Fakultas Kesehatan, Fakultas Sospol , Akademi Pariwisata 
sedangkan pada Fakultas Pariwisata dan Fakultas Psikologi, kebutuhan prestasi secara partial tidak signifikan mempengaruhi intensitas kewirausahaan.

\section{DAFTAR PUSTAKA}

Ajzen, I. (2005). Attitudes, Personality and Behavior. New York: Open University Press.

Adi Jaya Dan Seminari (2016) , Pengaruh Norma Subjektif, Efikasi Diri, Dan Sikap Terhadap Intensi Berwirausaha Siswa Smkn Di Denpasar, E-Jurnal Manajemen UNUD , Vol. 5, No. 3, 2016: 17131741 Issn : 2302-8912

Andika, M., \& Madjid, I. (2012). Analisis Pengaruh Sikap, Norma subjektif dan Efikasi Diri Terhadap Intensi Berwirausaha Pada Mahasiswa Fakultas Ekonomi Universitas Syiah Kuala (Studi Pada Mahasiswa Fakultas Ekonomi Universitas Syiah Kuala). Eco-Entrepreneurship Seminar \& Call for Paper "Improving Performance by Improving Environtment", 190-197.

Bryan (2018) Pengaruh Efikasi Diri Dan Pendidikan Terhadap Intensi Kewirausahaan Dengan Lingkungan Sosial Sebagai Variabel Moderasi ,Jurnal Manajemen Bisnis Dan Kewirausahaan/Volume 02/No.3/Mei-2018 : 46-53 JURNAL ILMIAH

Baumol, W. J., Litan, R. E., \& Schramm, C. J. (2007). Sustaining entrepreneurial capitalism. Capitalism and Society, 2(2) Article 1. Available at: http://www.bepress.com/cas/vol2/iss2/art1

BPS Jawa Timur 2019, https://jatim.bps.go.id/indicator/6/54/3/tingkatpengangguran-terbuka-tpt-provinsi-jawa-timur.html

Costa, T. G. da, \& Mares, P. (2016). Factors Affecting Students's Entrepreneurial Intentions of Polytechnic Institute of Setubal A Cognitive Approach. Revista de Administração, Contabilidade a Economia Da Fundace, 7(1), 102-117.

Cromie, S., 2000. "Assessing entrepreneurial inclinations: some approaches and empirical evidence". European Journal of Work and Organizational Psychology 9 (1): 7-30.

Dinc, M. S., \& Budic, S. (2016). The Impact of Personal Attitude, Subjective Norm, and Perceived Behavioural Control on Entrepreneurial Intentions of Women. Eurasian Journal of Business and Economics, 9(17), 23-35.

Defriana, Sri. 2011. Pengaruh Sikap (Attitude) terhadap Persepsi Kelayakaan (Perceived Feasiility) berwirausaha dan dampaknya terhadap Intensi berwirausaha Mahasiswa Universitas Negeri Padang

Farida, I., \& Mahmud. (2015). Pengaruh Theory Planned Of Behavior Terhadap Intensi Berwirausaha Mahasiswa. Forum Bisnis dan Kewirausahaan Jurnal IImiah STIE MDP, 5, 39.

Ferdinand, 2014, Metode Penelitian Manajemen, Edisi 5, UNDIP PressISBN: 979-704-254-5 
Hisrich, R. D., Peters, M. P., \& Shepherd, D. A. (2017). Entrepreneurship (10th ed.). New York: Mc Graw Hill Education

Herryanto \& Gantini, 2015, Analisis Data Kuantitatif dengan Statistika Deskriptif, ISBN: 9786023741144 Penerbit: Yrama Widya

BUKU

https://ekbis.sindonews.com/berita/1455746/34/angka-pengangguran-diindonesia-capai-705-juta-di-agustus-2019

https://www. facebook.com/HIPMIPTUNAND/posts/zimmerer-200212menyatakan-salah-satu-faktor-pendorong-pertumbuhankewirausahaan/794097717312190/

Griffin, R. W., \& Moorhead, G. 2013. Organizational Behavior: Managing People and Organizations, Ninth Edition. Mason: South-Western

Indarti, N., \& Rostiani, R. (2008). Intensi Kewirausahaan Mahasiswa : Studi Perbandingan Antara Indonesia, Jepang dan Norwegia Intensi Kewirausahaan Mahasiswa. Jurnal Ekonomi Dan Bisnis Indonesia, 23(4), 1-27.

Jaya, I. P. B. A., \& Seminari, N. K. (2016). Pengaruh Norma Subjektif, Efikasi Diri, dan Sikap Terhadap Intensi Berwirausaha Siswa SMKN di Denpasar. EJurnal Manajemen Unud, 5(3), 1713-1741.

Krueger, N.F.,Reilley,M.D., and Carsrud,A.L. (2000). "Competing Models of Entrepreneurial Intentions" Journal of Business Venturing, 15(2),pp.411- 432.

Katz, J., dan W. Gartner, 1988. "Properties of emerging organizations". Academy of Management Review 13 (3): 429-441

Lee, J., 1997. "The motivation of women entrepreneurs in Singapore". International Journal of Entrepreneurial Behaviour and Research 3 (2): 93-110.

Luthans, F. (2008). Perilaku Organisasi. Jogjakarta: Andi.

Mardliyah, U., Minarsih, M. M., \& Warso, M. M. (2016). Pengaruh Sikap, Norma Subjektif dan Efikasi Diri Terhadap Intensi Berwirausaha Pada Remaja Lulus SMK/SMA (Studi Kasus Pada Kelurahan Padangsari Banyumanik Semarang). Journal Of Management, 2(6).

McClelland, D., 1961. The Achieving Society, Princeton, New Jersey: Nostrand.

McClelland, D., 1971. The Achievement Motive in Economic Growth, in: P. Kilby (ed.) Entrepreneurship and Economic Development, New York The Free Press, 109-123.

Mutohar.2017. Pengaruh Kebutuhan Berprestasi Efikasi Diri Kesiapan Instrumen dan Pendidikan Kewirausahaan Terhadap Intensi Berwirausaha Mahasiswa. Jurnal Manajemen Kewirausahaan Vol. 16 No. 2008

Nugroho, Bhuono Agung. 2005. Strategi Jitu Memilih Metode Statistik Penelitian dengan SPSS. Jogyakarta: Andi Offset.

Prayitno, \& Duwi , 2010 . Paham Analisa Data Statistik Dengan SPSS. Mediakom, Yogyakarta 
Prabandari, S. P., \& Sholihah, P. I. (2014). The Influence of Theory of Planned Behavior and Entrepreneurship Education towards Entrepreneurial Intention. Journal of Economics, Business, and Accountancy Ventura, 17(3), 385-392

Prayitno, \& Duwi , 2010 . Paham Analisa Data Statistik Dengan SPSS. Mediakom, Yogyakarta

Ramayah, T., \& Harun, Z., 2005. Entrepreneurial Intention Among the Studenof Universiti Sains Malaysia (USM). International Journalof Management and Entrepreneurship, Vol. 1pp. 8-20

Scapinello, K. F., 1989. "Enhancing differences in the achievement attributions of high and low motivation groups". Journal of Social Psychology 129 (3): 357-363.

Sengupta, S. K. dan S. K. Debnath, 1994. "Need for achievement and entrepreneurial success: a study of entrepreneurs in two rural industries in West Bengal". The Journal of Entrepreneurship 3 (2): 191-204.

Suharti, L. dan Sirine. H. (2011). Faktor-Faktor yang Berpengaruh Terhadap Niat Kewirausahaan (Entrepreneurial Intention) (Studi Terhadap Mahasiswa Universitas Kristen Satya Wacana, Salatiga). Jurnal Manajemen Dan Kewirausahaan, Vol.13, No. 2, September 2011: 124-134.

Surya (2017) Kajian Empiris Entrepreneurial Intention Mahasiswa Stie Ama Salatiga, Jurnal IImiah Among Makartivol 10, No 19 (2017)

Sarwoko (2011), Kajian Empiris Entrepreneur Intention Mahasiswa Endi Sarwoko , JURNAL EKONOMI BISNIS, TH. 16, NO. 2, JULI 2011

Siswati (2019) Pengaruh Efikasi Diri, Norma Subjektif, Dan Pendidikan Kewirausahaan Terhadap Intensi Berwirausaha Mahasiswa Pendidikan Ekonomi Angkatan 2016 Universitas Negeri Semarang, Http://Lib.Unnes.Ac.Id/35884/1/7101415041 Optimized.Pdf

Suyanto,2000, Refleksi dan Reformasi Pendidikan di Indonesia Memasuki Milenium III, (Yogyakarta: Adicita 2000), 80.

BUKU Scapinello, K. F., 1989. "Enhancing differences in the achievement attributions of high and low motivation groups". Journal of Social Psychology 129 (3): 357-363.

Sugiyono, 2012, Statistika Untuk Penelitian. Bandung: Alfabeta

Sinha, T. N., 1996. "Human factors in entrepreneurship effectiveness". Journal of Entrepreneurship 5 (1): 23-29.

Tunjungsari, H. K., \& Hani. (2013). Pengaruh Faktor Psikologis dan Kontekstual Terhadap Intensi Berwirausaha Pada Mahasiswa. Proceeding Seminar Nasional Dan Call For Papers Sancall 2013, 425-432.

Wiyanto, H. (2014). Pengaruh Efikasi Diri dan Lingkungan Terhadap Niat Berwirausaha Mahasiswa (Studi pada Mahasiswa Program Studi Manajemen Fakultas Ekonomi Universitas Tarumanegara). Jurnal Manajemen. 18 (1), 114-129. 
Wijaya, T., Nurhadi, \& Kuncoro, A. M. (2015). Intensi Berwirausaha Mahasiswa : Perspektif Pengambilan Risiko. Jurnal Ekonomi Dan Bisnis Indonesia Siasat Bisnis, 19(2), 109-123.

Wulan Oktabriyantina, R. Gunawan S., Pujiati. (2014). Hubungan Locus Of Control dan Motivasi Berprestasi Dengan Self Efficacy Dan Minat Berwirausaha. Jurnal Pendidikan Ekonomi PIPS FKIP Unila

Yuhendri.(2013). Pengaruh Kebutuhan Akan Prestasi, Lokus Kendali, Dan Efikasi Diri Terhadap Minat Berwirausaha:Survey Pada Mahasiswa Fakultas Ekonomi Universitas Negeri Padang.S2 Thesis, Universitas Pendidikan Indonesia

Choo, S., dan M. Wong, 2006. "Entrepreneurial intention: triggers and barriers to new venture creations in Singapore". Singapore Management Review 28 (2): 47-64.

Zimmerer, Scarborough, \&Wilson. (2008). Kewirausahaan dan Manajemen Usaha Kecil Buku 1. (Alih Bahasa: Deny Arnos K dan Dewi Fitriasari). Jakarta: Salemba Empat. 